\title{
The Distinctive Features of Belarusian Traditional Funeral Repasts
}

\author{
Tadevush A. Navahrodski \\ Belarusian State University \\ Minsk, Belarus
}

\begin{abstract}
In Belarusian traditional culture, the funeral repast was an important part of the structure of funeral rites. Its meaning had as much to do with ethics as with sustenance and it was a required or normative part of funerary behaviour in the Belarusian social milieu. The memorial repast fulfilled many functions in Belarusian traditional culture. It served to commemorate ancestors and to link the living with their past. The meal performed a sacred or religious function, expressing faith in the afterlife. It performed an educational function and helped create family solidarity and promote willingness to learn about the family's genealogy (radavod).
\end{abstract}

The article, based on folkloric and ethnographic materials from the nineteenth and early twentieth centuries and on the results of field work conducted by the author, discusses two types of funeral repasts. One type is conducted on the day of internment and the other type includes the meals that correspond to the folk calendar and commemorate the dead. The article examines the distinctive features of funeral repasts in traditional Belarusian culture and explicates the function and meaning of specific funeral meals.

The meal (trapeza) is an important component of Belarusian traditional culture. Traditional Belarusian meals typically have several dishes or courses and several beverages in appointed order. Everyday meals are a central feature of life. They fulfill the main functional role in Belarusian cuisine and constitute the core of the entire system of nutrition. Festive and ritual repasts are seen as distinctive from the everyday meal. They are set in opposition to ordinary dining and the main feature of the holiday meal is the serving of richer foods and a greater variety of them. When examining the repast as an element of folk cuisine, it is important to pay attention to different factors such as the number of meals served, the time when and the place where the food is eaten, and the participants in the repast and their roles. It is also important to examine the courses served and the sequence in which they 
are presented. The behaviour of the participants and the codes of their performance during the meal are other important details to consider. Moreover, the wider cultural context of the traditional meal and the fixed connotations that it carries or messages that it transmits are of interest for ethnological analysis.

In Belarusian traditional culture, the funeral repast was an important part of the structure of funeral rites. Its meaning had as much to do with ethics as with sustenance and it was a required part or normative part of funerary behaviour in the Belarusian social milieu. Providing food was a way for the relatives of the deceased to show their appreciation to those who participated in the funeral rituals. It was a way to thank those who had supported the family in the difficult time that came with death and burial. Furthermore, the funeral repast had a strictly ritual aspect, and one of its main goals was to show respect for the soul of the deceased. According to Orthodox Christian beliefs, the soul of the departed person stayed in the home for nine days after the person died and only then journeyed to heaven. Thus it was important to honour this soul and please it. Folk belief held that all dead ancestors, not just the newly deceased, were invisibly present at the repast table and had come to later accompany their kinsman on the journey to the other world. To honour those spiritually present, the main dishes of the funeral repast were obligatorily different from those served on normal days.

In traditional Belarusian culture, there are two types of funeral repasts. The first type of repast was a ritual meal served on the day of burial. The other type was the less lavish subsequent ritual dinners prepared on the third, on the ninth, and on fortieth day after death, and then half a year from the date of death. A meal on the sixth day is also attested. The second type of meal was meant for close family members only.

Following a centuries-old custom, the meal on the day of internment occurred immediately after the burial of the deceased. It was a lavish repast and people believed that the deceased would be offended and get angry if an inadequate meal was served. In addition, every family considered that the deceased had earned the respect of his relatives during his or her lifetime. Thus each family unit tried to send their relative off on his or her last journey according to all the proper and conventional norms; they sought to execute the traditional folk code of what it meant to be human.

During funeral repasts the members of the deceased's family endeavoured to perform all the proper ritual and magical activities and to 
adhere to all appropriate customs and traditions. Hence, in Vil'nia province for example, after the funerals, the relatives of the deceased put a white table-cloth on the table or bench where the deceased had laid in state before burial. Then they put a glass of water and a ruchnik (ritual towel) on this bench or table. The purpose of these items was to allow the soul of the deceased to wash its hands before joining the funeral repast. The set-up with the glass and the towel had to remain in place for five to six days and no one was to disturb the items [Kirkor 1882: 283]. In the Mstsislaul' region, women who arrive at the house where the deceased had lived and his body now lay in state would touch the oven three times. According to local custom, performing this ritual would insure that the household would not be plagued with additional deaths and funerals [Romanov 1912: 528].

The first type of funeral repast, the one conducted on the day of internment, often carried a name that was derived from the main dish served during the event. Thus, one name for this meal was "harachki" and this term was based on the name of a hot wheat bread (palianitsa), which was not supposed to be cut. To avoid the use of a knife, guests pinched off pieces of bread to eat. Another name for the meal was "kliotski" (dumplings) and it was, of course, taken from the name of this food. In some regions, the names of these dishes were so strongly associated with death that they appear in proverbs and sayings as euphemisms. Thus, when referring to a hopelessly sick person, people might say: "Ну, клёцкі яму" ["Well, dumplings to him"]. This meant that people anticipated that the person in question would die and that his relatives would soon be preparing a funeral repast. [Vasilevich 1986: 28].

Before a funeral repast began, a priest would perform the Litany to commemorate the deceased and to bless the meal [Romanov 1912: 526]. After this religious ritual and only after the ritual would the hosts invite their guests to sit down at the table. According to tradition, the place of greatest honour was given to the oldest person present at the funeral. The explanation for this practice was that it not only showed a respectful attitude toward the elderly, but also acknowledged the fact that the oldest person might well be the next one to die. This custom was seen as an expression of the natural order of things and was accepted by all as proper and rational. People made sure that young people did not leave the funeral repast earlier than others because another belief held that early departure from a funeral meal was connected to or presaged an early death. In the Bykhau district, the men sat under the icons or as close to pokuts' (icon corner) as possible. Women sat at the other end of 
the table or even at a separate table [Romanov 1912: 520]. Belarusians from the Smalensk region placed those people who dug the grave, made the coffin, and sewed clothes for the deceased under the icons, in other words in the place of greatest honour. Other participants in the last rites were invited to sit at the funeral table only after those who had helped with the funeral were seated. While at the table, the participants of the funeral repast tried not to sit close to each other so as "not to crowd out the ancestors who invisibly participate in the conversation" [Dobrovol'skii 1894: 315]. According to Chubinskii, all hired people who worked on the farm or in the household also participated in the repast. However, they sat at a separate table somewhere in the yard [Chubinskii 1877: 710]. The nature of the repast depended on the family's prosperity. If the family was poor and was not able to provide a full meal then the participants of the funeral were offered kutstsia at the graveyard. However, this practice was resorted to only in cases of utmost poverty.

The funeral repast necessarily included special ritual dishes. The most important among these are kanun ('kanon'), kutstsia, koliva ('poliva', 'kolyvo'), syta, harachyki, kliotski. These ritual foods were prepared differently in different parts of Belarus. For example, one way of preparing kanun was to take water sweetened with sugar or honey and to crumble bread product into this liquid. The bread product could be actual bread or bagels or anything else made of dough. Kutstsia could be made from any of a number of grains such as rice, millet, buckwheat or barley. At the funeral repast, unlike at other meals, it had to be sweet. In the Mahileu district, kutstsia was served with raisins. Sometimes a cross baked out of dough with raisins on top was placed atop the kutstsia or stuck into it [Romanov 1912: 530; Chubinskii 1877: 710].

Traditionally the funeral repast began with kutstsia or kanun. The guests took one or three spoons of kanun from a common bowl, passing it from one person to the other. This practice continues into the present. During the repast the peasants of Vil'nia and Smalensk districts poured one spoon of every meal onto the table. This was said to be an offering "dlia bats"kou" ("for parents or forefathers, in other words for ancestors"). Sometimes guests poured their first glass of wine and the first spoon of every ritual dish that they received into the corner where the deceased had laid in state before the burial [Kirkor 1882: 283; Iurkevich 1853: 290; Dobrovol'skii 1894: 315].

After drinking their first glass of vodka, an obligatory toast, the participants of the rite ate pancakes followed by borsch with meat or 
cracklings. If the funeral repast took place during Lent then the borsch was prepared with fish or "muchnaia zataloka" (flour thickener) and hemp oil. Other dishes might include omelettes (iaeshnia), sausages (kaubasy), stewed cabbage, noodles, pastry with meat or other filling, and fried potatoes. The meal concluded with halushki (dumplings) made of wheat or buckwheat flour. Halushki, as well as kanun and kutstsia, were absolutely obligatory to the funeral repast whereas the inclusion or exclusion of the other dishes was optional [Romanov 1912: 526; Shein 1902: 73; Dobrovol'skii 1892: 315].

In the Mahileu region, the funeral repast started with kanun, and ended with kutstsia. It should be noted that the main funeral meal had to be hot and had to produce steam [Navahrodski 2000: 72]. Steam could come from borsch, from krupnik (a soup made of groats) or some other dish. The steam was believed to be a necessary component because the souls of the dead inhaled the steam as sustenance. In the Horki district, cabbage, potatoes, and groats were cooked. In this area, the participants of the rites drank three glasses of vodka only [AIMEF 1993: p. 58]. In the Krychau district (Mahileu region), the repast usually ended with kliotski (dumplings). Because of the ubiquity of kliotski, in the Horki district (village of Dobrae), the relatives of the deceased invited guests to the memorial repast by saying "Прыходзьце на клёцкі" ["Come for dumplings"] [AIMEF 1993: p. 58].

In many places, the hot wheat bread called palianitsa was a required item on the table. It was not cut with a knife and guests had to tear pieces off with their fingers. According to folk belief the steam which came out of the hot bread, like the steam from the various dishes, acted as food for souls of the dead ancestors invisibly attending the funeral repast [Romanov 1912: 526; Vasilevich 1986: 28].

During the repast, a place was set at the table for the deceased. The place setting included a glass, a bowl, and a spoon. The glass was filled with vodka in order to satisfy the deceased's thirst. Food for the departed was usually put on the plate or directly on the tablecloth. It is noteworthy that, even in the twenty first century, Belarusians will not start the funeral repast without performing the ritual of setting a place for the deceased and serving him food and drink. The belief that the deceased would feel better and would help the family if his or her soul was treated properly at the funeral table was preserved in folk consciousness for centuries and into the present.

There is another type of funerary meal which corresponds to the folk calendar. This type of meal does not have distinctive features such 
as obligatory dishes or a set order of presentation. Instead, this type of repast is a social event. Meals commemorating the dead take place at several points in the calendar cycle. They come in spring (Radaunitsa, Vialikdzen' [Easter]), in summer (Traetskiia Dziady), in fall (Zmitrauskiia Dziady, Asianiny), and in winter (Maslenichnyiia Dziady).

All the memorial meals that are called Dziady are celebrated on their proper days and are vivid remnants of a cult of ancestors. They are also a symbol of the deep humanity of the Belarusians. The term "Dziady" [Forefathers] referred to all the dead ancestors of any age and sex or to their souls. For the Belarusians, their ancestors embodied their living spiritual and physical roots [Vasilevich 1986: 31]. Celebration of Dziady was viewed as the first and foremost duty of a human in almost every area of Belarus. The people believed that in the days called Dziady the souls of dead ancestors came down to Earth from Heaven to see how their descendants were doing and to determine if they respected the memory of the deceased and took care of their heritage. All of these beliefs encouraged strict fulfillment of ritual demands and the execution of appropriate acts.

The Dziady can be divided into two groups according to the way that they were celebrated. One type was the commemoration rituals held in the home and the other was rites performed in the cemetery, where the dead ancestors were buried. Zmitrauskiia Dziady was the most important commemoration day from the first group, and Radaunitsa (Radunitsa) was the most important event from the second.

Belarusians made extensive preparations for Dziady memorial repasts and they did them well before the actual commemorative day. In wealthy families, a one-year-old hog, lamb, or a bull calf was typically slaughtered and it was considered prestigious for the housewife to cook many meat dishes. The number of dishes was determined not only by family's wealth, but also by a ritual convention. Ethnographers have determined that the number of dishes ranged from five to fifteen.

The dishes were served in a certain order: kanun with bagels (baranki; abaranki); a sour dish (rasol) made with beetroots and meat; krupenia, a soup made of groats and potatoes, bul'biashnik, a potato soup, halushki (dumplings or noodles), boiled meat, ladki, aladki (pancakes) which were considered especially appropriate for dead children, iushka (broth) with onions and carrots, or parsnip cooked with milk, tvaroh (cottage cheese) with sour cream, iaechnia (omelette), then kasha. The order could be modified slightly but it was absolutely necessary that kanun be the first dish and that omelette or kasha be the 
dish served at the end. Homemade vodka (harelka) was drank after kanun was served for supper [Romanov 1912: 549]. For Lenten or fasttime Dziady when meat was not allowed, peas, kvass with mushrooms, and fish and kasha were typically prepared. For Dziady that came outside of Lent, the meals were more varied and richer foods were prepared. They would include pancakes and salt pork, boiled meat, kvashanina (fermented vegetables), cabbage with meat, krupnik, kasha with meat, and other dishes [Shein, 1902: 373]. A saying about non-Lenten Dziady goes as follows: "Гэта такое свята, што ні сесці, ні легчы" ["This is the sort of holiday that [after the meal] you can neither sit, nor lie [meaning that you will be too full]"]. This saying emphasizes the fact that no other event offers the opportunity to eat so much.

In the Pinsk region, after returning from the graveyard, Belarusians ate a memorial supper in a special fashion. In the evening, those who had participated in the memorial meal covered the table with a white tablecloth, and set out dishes with beans or peas and syta (water with honey). They served poliuki made of fish and meat stock in two flavours: sweet and sour. Other foods included roasted salanina (corned meat), pancakes, omelette with sausage; millet or buckwheat kasha, and sour milk or "milk" made of poppy seeds ground and diluted with water. In the middle of the table it was traditional to place a loaf of bread. Also bread slices in stacks of three or small loafs of bread were placed around the table at the spots where honoured participants were expected to sit.

While the lavish supper was cooking, the windows and doors remained open and the elderly members of the family walked around the house, praying and looking in the direction of the graveyard. By doing so, they symbolically invited deceased ancestors to the repast. After performing this ritual, the elderly returned to the house and sat quietly at the table, "listening" to the voices of the deceased and their conversations. When the lady of the house felt that the ghosts were properly sated with the food or steam presented to them, she made a sign to the master of the house. This indicated that it was time for him to sit at the table. He, in turn, invited all the participants of the funeral rite to sit down and have supper. The master of the house took the food first and he began with syta with beans or peas or with kutstsia. His first action upon taking the food was to offer food to the ancestors. This could be done by putting sacrificial portions of the meal into a special, separate bowl. After the head of the household performed the ritual of serving himself and honouring ancestors, the same ritual was repeated by the housewife and other participants of the memorial repast. In the same manner, the 
master and the lady of the house took a bit from every dish served during the course of the meal and placed it on separate plates for the spirits of the ancestors. After finishing the celebration, the food that had been set aside for spirits was given to children. Some people believed that, if the children ate this ritual food honouring ancestors, they would not be frightened by thunderstorms and lightning. Others gave the part of the memorial food set aside for ancestors to livestock or poultry. In the latter case, it was left on the roof of the house. Some folks brought the food from the memorial repast down to rivers, lakes, or ponds and threw or poured this ritual food or leftovers into the water for the sake of the souls who had died by drowning. Sometimes the leftovers of the ritual commemorative meal were taken out to graveyards where the supper was finished together with the ancestors [Hurski 2003: 292-3]. Another way of honouring ancestors was for each guest to take a spoonful of each dish and pour it on the table. Sometimes, people left homemade vodka for their ancestors on window-sills. Vodka was also left in doorways and these were left open to let the dead ancestors enter the home and participate in the supper.

A detailed description of the Dziady memorial repast made in 1891 goes as follows:

Вячэраюць у гэты дзень не так, як у звычайныя дні. Кожны, хто зачэрпнуў раз, кладзе лыжку на стол. Лыжка павінна ляжаць на стале столькі часу, колькі неабходна для таго, каб гэтай лыжкаю мог зачэрпнуць другі. Каму не даспадобы звычай класці пасля кожнага глытка на стол лыжку, дык гэта дзецям. Прагаладаўшыся за цэлы дзень (на дзяды абеду няма), дзіця хацела б хутчэй задаволіць свой апетыт, а тут нельга, дарослыя загадваюць класці лыжку. “Навошта гэта?” пытаецца малое. "Вось бачыш, - тлумачаць дарослыя, - каля кожнага 3 нас сядзіць нябожчык (памерлы): ты зачэрпнеш адну лыжку, і яму трэба зачэрпнуць адну. Вось для гэтага і трэба класці лыжку, а калі ты не будзеш класці, то твой нябожчык устане 3-за стала галодным. Ён разгневаецца і пакарае цябе за гэта. - “Але ў нас ёсць яшчэ лыжкі, кажа дзіця, - трэба пакласці на стол, няхай сабе нябожчык есць, колькі захоча". - "Не нельга, галубок! - зноў тлумачаць дарослыя. - Нябожчык можа есці толькі тою ляжкаю, якою есць жывы, каля якога ён сядзіць, а другую лыжку ён не можа ўзяць, калі б яна і была на стале.

[On those days people have supper in a manner that is different from ordinary days. Everyone who has taken a spoonful of food must then place the spoon on the table. The spoon has to lie on the table as long as would be needed if another person were to take that spoon and help himself. The ones who resent the custom of putting the spoon down after every sip or every bite are the children. They get hungry during a day because there is no lunch on Dziady days and so they want to satisfy their appetites. But eating fast in not allowed; adults insist that the spoon be placed on the table after every sip. The child 
then asks, "Why must I do this?" "You see", the adults explain, "The dead ancestors are sitting next to each of us: so you will take a spoonful and they will take a spoonful. That is why you need to put the spoon down, because if you did not, your forefather would leave the table hungry. He would get angry and punish you for that". The child answers, "But we have more spoons. Why not put them on the table and let the dead eat as much as they like". "No, we must not do that, dear!" the adults explain again. "The deceased can eat only using that spoon, which is used by the living who sit next to them. And they cannot use another spoon, even if it were be put on the table.

The child is thus convinced by the arguments presented by the adults and puts the spoon on the table after every sip [L.S. 1891: 2]

This description shows that location of the spoon during the memorial repast had a specific meaning. The behaviour of the participants acknowledged that the dead participate in the meal along with the living. There is also evidence of concern over interference on the part of dark forces. An example is the saying: “Зачэрпнуў лыжку, зараз жа пераверні яе: калі лыжка неперавернутая, да яе можа дакрануцца чорт" ["When you've helped yourself to a spoonful, turn the spoon over right away. If you don't turn the spoon over, the devil can touch it"] [Dobrovol'skii 1914: 164]. Fear of the devil was in conflict with the fact that it was important to let the ancestors eat. We see this in the following: "The spoon has to be put on the table to let the forefathers eat. And it is important that the spoon be placed hollow side up. If this is not done, the dead will turn over in their graves. If somebody puts down the wrong way, that is turned over, the elderly notice this mistake and reprimand the person who made it." (Mahileu huberniia) [Shein 1902: 611]. According to A. L. Toporkov, this behaviour actualizes the isomorphism of the spoon [Toporkov 1991: 196]. After the supper, the dishes with food were not removed from the table, but left overnight. People believed that the forefathers would come and treat themselves to food during nighttime. One of the dwellers of the village Paselishchy (Khoiniki district, Homel' oblast), a woman named Sof'ia Mitrafanauna Iautushenka recalled, "Бацькі нам загадвалі верыць, і мы гаварылі: "Мама, ужо менш у місцы боршчыку" [“The parents told us to believe, and we would say, 'Mama, look, there is already less borsch in the bowl."'] [AIMEF 1992, p. 30]. M. V. Dounar-Zapol'ski gives an interesting example of what happens at the end the repast: "The master or the lady of the house takes a full cup of water and throws its contents from the direction of the table toward the entrance door saying: 'Што не даелі, не дапілі, то ідзіце на папер на двор' [If you have not eaten and 
drunk enough, then go out into the yard]. People believed that these words would prevent the souls of the dead from staying in the home until the next Dziady commemoration" [Dovnar-Zapol'skii 1909: 305].

In the Vitsebsk region, the Dziady ritual meal consisted of iushnik, a broth made of meat with blood, sausages, and pancakes. All the conversations during the repast were exclusively about the deceased members of the family. The conversation was started by the oldest member of the family after people had drunk their first glass of vodka. All the ancestors were recalled and remembered, from the deceased relatives closest to the living to those from the distant past. After supper, the conversation was supposed to last until the third crowing of the roosters (da tretsikh peuniau, in other words, until after midnight). Those present recalled the various adventures of their deceased relatives. They talked about their personalities and told family and ancestral legends [Hurski 2003: 294]. In area of the Dzisna-river (Vitsebsk region), the family invited about ten neighbours to celebrate Dziady. The main dish served for supper was iushnik. However, if a hog was not slaughtered for this feast, then dumplings with "souls" ( $z$ dushami) were prepared. This is a special kind of dumpling made by wrapping cracklings in dough. Another possible dish was pancakes with verashchaka (fritters - dough deep-fried in lard). An alternative to pancakes with fritters was sausages with cabbage. Salamatka (dried apples, pears, and berries cooked and served with honey) or an oat kisel' (pudding) with honey syta were offered for dessert. As a rule, people cooked more food than was needed, and the leftovers of meat, pancakes, and other foodstuffs were distributed among the poor. As a result every neighbour invited to a Dziady celebration returned home with something [Hurski 2003: 66-9].

In the Mahileu region, the housewives split the very first pancake made for Dziady into pieces and put it on the windowsill as an offering to the ancestors. The village herders knew about this custom and, going through the village, stopped at every house and asked: "Гэй, гаспадыня! Ці пякла бліны? Прыслалі дзяды па бліны, свінкі па саланінкі, авечкі па яечкі, баранкі па соль, а кароўкі па сыр" [“Hey, missis! Did you make pancakes? The ancestors sent me for pancakes and pigs for corned meat, sheep for eggs, rams for salt, and cows for cheese"]. In response, the housewives brought out everything that the herder asked for. In those families where children were sickly and where many children had died, special pancakes called ladki were prepared. People believed that this would help prevent sicknesses and subsequent death within that family and help preserve their living offspring. After taking a 
bath in the bathhouse (laznia), the housewife took all the pots with food out of the oven and put them on a bench near the stove, arranging them in a certain order. Dishes that were supposed to be served first during the ritual dinner were placed closest to the table. Then came the dishes that would be served next, and so forth. At the same time the master of the house lit the candles in the icon corner and all the members of the family prayed. During the time of the prayer, the oldest member of the family took a broken piece of pottery, and put several burning coal pieces in it. On the top of the coal he put a tuft of herbs that had been blessed in church on Whit Monday. Then, he fumigated the pots with the meal, the table with the spoons, goblets and bread, and then the entire house. A candle was left burning from the time of the prayer until the kanun was finished. The number of dishes for Dziady had to be odd. Among the most popular dishes were kanun, poliuka, milk, dumplings, omelette, and kasha. Meat was considered a separate dish. All the dishes were served in a certain turn, as mentioned above. Sometimes the meat from the poliuka was served alone as the last course. In other families, the meat was served immediately after the poliuka. All meals had to be eaten with pancakes instead of bread. When the members of the family and their guests sat down at the table, they began their meal with kanun. It was considered obligatory to try at least a little bit from every dish. It was believed that the deceased ancestors would be angry if this was not done. Another belief held that, if some food was dropped on the floor, it should not be picked up. According to a saying: "Нехта есці хоча" [[dropping the food means that] "Somebody wants to eat it"]. All the participants of the repast had to get up from the table together. This was a custom necessitated by the belief that, if somebody would get up from the table before the others, he or she would die before them also. After the supper, the housewife would clean the table and remove the pancakes that had been left on the windowsills [Shein 1902: 608-12].

In the Minsk region one of the ritual dishes cooked was the head of a ram or a hog. If people could not afford to slaughter such a large animal, then at least the head of a chicken had to be on the ritual table. The master of the house held a candle wrapped in a pancake in one hand and a loaf of bread in the other and made three circles around the table, starting at the head of it. He recited the names of deceased ancestors and relatives and even mentioned those who had lived earlier on the lands that he now possessed. The master invited them to the ritual meal, saying "Прыбывайце к сталу!" [Come to the table!]. Sitting down to the meal, the participants poured a few drops from their glasses on the table and 
said "Прыбывайце!" [Come!]. After finishing the memorial repast, all the dishes were left on the table, spoons and knives, included. People did this because they were convinced that the deceased would come during the night and treat themselves to the meal [Tyszkewicz 1847: 378-9]. In Palesse, for example, during the Dziady repast, people refrained from putting their feet on the crossbars under the table because they believed that the souls of the dead could be sitting there like birds perched on branches. Putting ones feet on the crossbars could have offended and angered the ancestors [Serzhputouski 1998: 233].

The memorial repast fulfilled many functions in Belarusian traditional culture. It served to commemorate ancestors and to link the living with their past. The meal performed a sacred or religious function, expressing faith in the afterlife. It performed an educational function. The participation of children and teenagers in the memorial repast insured the transmission of the customs and belief of the clan from one generation to the next. The meal helped create family solidarity and promoted an interest in the family's past and thus a willingness to learn about its genealogy (radavod). Because of its deep meaning and its multifunctional nature, the funeral repast was and remains an important part of Belarusian culture.

\section{BIBLIOGRAPHY}

AIMEF Apхіў Інстытута мастацтвазнаўства, этнаграфіi і фальклору Нацыянальнай Акадэміі Навук Беларусі [Achieve of art history, ethnography and folklore of the National Academy of Science of the Republic of Belarus], фонд 6, воп. 13, справа 67

Chubinskii, P. Р. 1877. Чубинский П.П. Труды этнографическостатистический экспедищии в Западно-Русский край. ЮгоЗападный отдел. Материаль и исследования. Обряды, родины, крестины, свадьба, похороны. T. 4. [Proceedings of the ethnographic-statistic expedition to the Western Russian region. South-Western Department. Materials and research. Ritual, celebration of birth, baptising, wedding and funeral. Vol. 4] СанктПетербург: Императорское Русское географическое общество.

Dobrovol'skii, V. N. 1894. Добровольский В.Н. Смоленский этнографический сборник. Ч. II. [Smolensk ethnographic annual. Part II] Санкт-Петербург: Тип. Е. Евдокимова. 
Dovnar-Zapol'skii, M. V. 1903. Довнар-Запольский M.В. Исследования и статьи. [Research and articles] Киев: Тип. 1-й. Киевской артели печатного дела

Iurkevich, I. 1853. Юркевич И. “Остринский приход Виленской губернии Лидского уезда" [Ostrino parish of Vil'no guberniia, Lida uezd] Этнографический сборник ИРГО. Вып. I СанктПетербург: Изд. Имп. Русским Географическим обществом. 283-293

Hurski, А. I. 2003. Гурскі А.I. (compiler). Земляробчь каляндар. Абрады і звычаі [Farmers' calendar. Customs and rituals] Мінск: Беларуская навука

Kirkor, А. G. 1882. Киркор А.Г. “Народная жизнь” [Folk life] Живописная Россия. Т. 3. Ч. II. Мінск: Беларуская Энцыклапедыя. 277-288.

L. S. 1891. Л.С. “Дзеды” [Dzedy] Гродненские губернские ведомости. 97 - Неофициальная часть

Navahrodski, T. А. 2000. Навагродскі T.A. Традыцыi народнага харчавання беларусаў. [The traditions of folk nutrition of Belarusians] Мінск: НIA.

Romanov, E. R. 1912. Романов Е.Р. Белорусский сборник. Быт белоруса [Belarusian collection. The everyday life of Belarusian] Вып. 8. Вильно.

Serzhputouski, А. К. 1998. Сержпутоўскі А.К. Прымхі $і$ забабоны беларусай-палешукоц̆. [Superstitions and prejudices of Palesse Belarusians] Мінск: Універсітэцкае.

Shein, P. V. 1902. Шейн П.В. Материаль для изучения быта и языка русского населения Северо-Западного края. T. III. [Materials for analysis of the everyday life and language of the Russian population in the North Russian region. Vol. III] Санкт-Петербург: Тип. Импер. Академии Наук.

Toporkov, A. L. 1991. Топорков А.Л. “Структура и функции сельского застольного этикета у восточных славян” [The structure and functions of the rural table etiquette of Eastern Slavs] Этнознаковые функиии культуры. Москва: Наука. 190-203.

Tyszkewicz E. 1847. Opisanie powiatu Borysowskiego. [Description of the Borisov region] Wilno: Drukarnia Ant. Marcinowskiego. 378379

Vasilevich, U. А. 1986. Васілевіч У.А. (compiler) "Беларускія жалобныя абрады і галашэнні" [Belarusian mourning rituals and 
laments]. Пахаванні. Памінкі. Галамэнні. Мінск: Навука i тэхніка. 5-59.

Translated by Hanna Chuchvaha 